\title{
Virgibacillus koreensis sp. nov., a novel bacterium from a salt field, and transfer of Virgibacillus picturae to the genus Oceanobacillus as Oceanobacillus picturae comb. nov. with emended descriptions
}

\author{
Jung-Sook Lee, Jee-Min Lim, Keun Chul Lee, Jae-Chan Lee, \\ Yong-Ha Park and Chang-Jin Kim
}

Correspondence

Chang-Jin Kim

changjin@kribb.re.kr

\author{
Korea Research Institute of Bioscience and Biotechnology, 52 Oeundong, Yusong, Daejeon \\ 305-333, Korea
}

\begin{abstract}
A novel Virgibacillus strain, $\mathrm{BH} 30097^{\top}$, was isolated from a salt field near Taean-Gun on the Yellow Sea in Korea. Cells were Gram-positive rods and bore ellipsoidal endospores in terminal positions. The optimum $\mathrm{pH}$ and temperature for growth of this organism were $\mathrm{pH} 7$ and $25^{\circ} \mathrm{C}$, respectively. The main respiratory quinone was $\mathrm{MK}-7$ and the major cellular fatty acids were anteiso- $\mathrm{C}_{15: 0}$ and iso- $\mathrm{C}_{16: 0}$. Analysis based on 16S rRNA gene sequence data revealed that the isolate formed an evolutionary lineage distinct from other Virgibacillus species. Levels of sequence similarity between the isolate and other Virgibacillus species ranged from 93.8 to 96. $7 \%$. DNA-DNA relatedness values between strain $\mathrm{BH} 30097^{\top}$ and a phylogenetically closely related strain, Virgibacillus halodenitrificans $\mathrm{KCTC} 3790^{\top}$, were less than $24 \%$. On the basis of morphological, physiological and chemotaxonomic characteristics, 16S rRNA gene sequence comparison and DNA-DNA hybridization, a novel species, Virgibacillus koreensis sp. nov., is proposed, with the type strain $\mathrm{BH} 30097^{\top}\left(=\mathrm{KCTC} 3823^{\top}=\mathrm{JCM} 12387^{\top}\right)$. It is also proposed that Virgibacillus picturae be transferred to the genus Oceanobacillus as Oceanobacillus picturae comb. nov. based on its $16 \mathrm{~S}$ rRNA gene sequences and other taxonomic characteristics.
\end{abstract}

Aerobic, rod-shaped, spore-forming, moderately halophilic bacteria have been isolated from various environments. They were originally assigned to the genus Bacillus but subsequently reclassified into several genera such as Halobacillus (Spring et al., 1996), Gracilibacillus (Wainø et al., 1999), Virgibacillus (Heyndrickx et al., 1999), Filobacillus (Schlesner et al., 2001), Oceanobacillus (Lu et al., 2001), Lentibacillus (Yoon et al., 2002) and Pontibacillus (Lim et al., 2005) based on 16S rRNA gene sequence comparisons and chemotaxonomic characteristics.

The genus Virgibacillus was first proposed by Heyndrickx et al. (1998) based on polyphasic data from amplified rDNA restriction analysis (ARDRA), fatty acid profiles, SDS-PAGE patterns of whole-cell proteins and phenotypic

Published online ahead of print on 16 September 2005 as DOI 10.1099/ijs.0.63734-0.

The GenBank/EMBL/DDBJ accession number for the 16S rRNA gene sequence of strain $\mathrm{BH} 30097^{\top}$ is $\mathrm{AY} 616012$.

A photomicrograph showing sporangia and vegetative cells of the type strain of Virgibacillus koreensis is available as supplementary material in IJSEM Online. characterization, and its description was later emended by Heyrman et al. (2003). Members of the genus Virgibacillus bear oval to ellipsoidal endospores, are motile, Grampositive rods and have DNA G $+\mathrm{C}$ contents ranging from 36 to $43 \mathrm{~mol} \%$ (Heyrman et al., 2003). The halotolerant bacterium Bacillus salexigens (Garabito et al., 1997) was transferred to the new genus Salibacillus as Salibacillus salexigens (Wainø et al., 1999). Arahal et al. (2000) later proposed the reclassification of Bacillus marismortui as Salibacillus marismortui. Subsequently, Heyrman et al. (2003) proposed on the basis of genotypic and phenotypic data that Virgibacillus and Salibacillus should be combined in a single genus. Following the Rules of the Bacteriological Code (Lapage et al., 1992), the species of Salibacillus were transferred to Virgibacillus as Virgibacillus salexigens and Virgibacillus marismortui. Recently, Bacillus halodenitrificans, first described by Denariaz et al. (1989), was transferred to the genus Virgibacillus as Virgibacillus halodenitrificans (Yoon et al., 2004). The genus Virgibacillus comprises eight species at the time of writing.

We isolated a novel bacterium, strain $\mathrm{BH} 30097^{\mathrm{T}}$, from a salt field. The morphological, biochemical and phylogenetic 
distinctiveness of the isolate is described, and we consider that it should be assigned to a novel species of the genus Virgibacillus. As part of our study of this novel isolate, it became apparent that Virgibacillus picturae is closer to the genus Oceanobacillus than to Virgibacillus based on a phylogenetic analysis of their 16S rRNA gene sequences. $V$. picturae was described by Heyrman et al. (2003); at that time, Heyrman et al. (2003) studied the polyphasic characteristics of Virgibacillus picturae, but did not describe its phylogenetic relationship to the genus Oceanobacillus. The genus Oceanobacillus, with the single species Oceanobacillus iheyensis, was first described by Lu et al. (2001), and Oceanobacillus oncorhynchi was subsequently proposed by Yumoto et al. (2005). Therefore, to clarify the taxonomic position of $V$. picturae, we examined its phenotypic and chemotaxonomic characteristics, 16S rRNA gene sequences and phylogenetic relationships.

Strain $\mathrm{BH} 30097^{\mathrm{T}}$ was isolated from a salt field near TaeanGun on the Yellow Sea in Korea on a nutrient agar containing artificial sea water (ASW) including $7 \% \mathrm{NaCl}$. The isolate and reference strains, such as $V$. halodenitrificans KCTC $3790^{\mathrm{T}}$ and related Virgibacillus and Oceanobacillus species, were cultured on marine agar 2216 (Difco) for $48 \mathrm{~h}$ at $30^{\circ} \mathrm{C}$.

Cell morphology was examined by light microscopy and motility was determined with an optical microscope using the hanging drop technique (Skerman, 1967). The flagellum type was determined using transmission electron microscopy using cells from the exponential phase of growth, in which cells were negatively stained with $1 \%(\mathrm{w} / \mathrm{v})$ phosphotungstic acid and air-dried and the grids were examined using a transmission electron microscope (Philips). Anaerobic growth was recorded in an anaerobic chamber on marine agar. Growth experiments were performed using screwcapped tubes and growth was estimated by monitoring the $\mathrm{OD}_{600}$. The ability to grow with different added salt concentrations $(0-25 \% \mathrm{w} / \mathrm{v} \mathrm{NaCl})$ was tested with nutrient broth (Difco) as the basal medium. Growth at different temperatures was observed in trypticase soy broth at 10,15 , $20,25,30,35,40,45$ and $50^{\circ} \mathrm{C}$. Growth experiments at different $\mathrm{pH}$ values were performed using $10 \mathrm{ml}$ trypticase soy broth adjusted to $\mathrm{pH} 6 \cdot 0-10 \cdot 0$ (Sorokin, 2005); $100 \mathrm{mM} \mathrm{Na}_{2} \mathrm{HPO}_{4} / \mathrm{NaH}_{2} \mathrm{PO}_{4}$ buffer $(\mathrm{pH} \mathrm{6 \cdot 0-8 \cdot 0)}$ and $100 \mathrm{mM} \mathrm{NaHCO}_{3} / \mathrm{Na}_{2} \mathrm{CO}_{3}$ buffer $(\mathrm{pH} 9 \cdot 0-10 \cdot 0)$ were used. This experiment was performed based on the methods of Yumoto et al. (1998). API 20E and API 50CHB systems (bioMérieux) were used for physiological and biochemical characterization. All suspension media were supplemented with $7 \%(\mathrm{w} / \mathrm{v}) \mathrm{NaCl}$. All API tests were performed in accordance with the manufacturer's recommendations (bioMérieux). Catalase activity was determined by bubble production from $3 \%(\mathrm{v} / \mathrm{v}) \mathrm{H}_{2} \mathrm{O}_{2}$, and oxidase activity was determined using $1 \%(\mathrm{w} / \mathrm{v})$ tetramethyl-p-phenylenediamine.

Cells of the isolate were Gram-positive rods, motile by means of peritrichous flagella, that formed chains and/or filaments (see Supplementary Fig. S1 in IJSEM Online); ellipsoidal endospores formed in terminal positions (Supplementary Fig. S1). Strain BH30097 ${ }^{\mathrm{T}}$ formed circular, low-convex, smooth, semi-translucent and cream-coloured colonies. The isolate grew anaerobically and at an $\mathrm{NaCl}$ concentration of $0 \cdot 5-20 \%$; optimum growth was at $5-10 \%$ $(\mathrm{w} / \mathrm{v}) \mathrm{NaCl}$. The isolate grew at between 10 and $45^{\circ} \mathrm{C}$, but not at $50{ }^{\circ} \mathrm{C}$; optimum growth was observed at $25^{\circ} \mathrm{C}$. Strain $\mathrm{BH} 30097^{\mathrm{T}}$ grew at $\mathrm{pH} 5 \cdot 5-9 \cdot 0$, with an optimum at $\mathrm{pH} 7 \cdot 0$. The isolate tested positive for aesculin hydrolysis, $\beta$-galactosidase, oxidase and catalase activities and acid production from amygdalin, L-arabinose, cellobiose, aesculin, D-fructose, maltose and D-xylose. It gave negative results for nitrate reduction, indole production, D-glucose acidification, arginine hydrolysis, urease, gelatin hydrolysis and acid production from $\mathrm{N}$-acetylglucosamine, D-arabinose, galactose, L-fucose, glycerol, glycogen, myo-inositol, 5-ketoD-gluconate, mannitol, D-mannose, D-melibiose, L-rhamnose and D-turanose.

For total cellular fatty acid analysis, cells were cultured on trypticase soy agar for $48 \mathrm{~h}$ at $30^{\circ} \mathrm{C}$ and the fatty acids were extracted following the procedures for the Microbial Identification System (MIDI, Inc.), as described previously (Lee et al., 1996; Yang et al., 1993). Isoprenoid quinones were extracted with chloroform/methanol $(2: 1, \mathrm{v} / \mathrm{v})$, and purified by TLC on Merck Kieselgel $60 \mathrm{~F}_{254}$ plates $(20 \times 20 \mathrm{~cm}, 0.5 \mathrm{~mm}$ thickness $)$ using petroleum ether/ diethyl ether $(9: 1, \mathrm{v} / \mathrm{v})$ as the solvent. The identity of the quinones was determined by HPLC, as described by Shin et al. (1996). Diaminopimelic acid (DAP) isomers were determined using the method of Komagata \& Suzuki (1987). Extraction and analysis of polar lipids by two-dimensional TLC were performed according to the methods of Komagata \& Suzuki (1987).

Whole-cell fatty acid profiles for strain $\mathrm{BH} 30097^{\mathrm{T}}$ and related Virgibacillus and Oceanobacillus species are shown in Table 1. Major fatty acids $(>1 \%)$ in strain $\mathrm{BH} 30097^{\mathrm{T}}$ were anteiso- $\mathrm{C}_{15: 0}(43 \cdot 42 \%)$, iso- $\mathrm{C}_{16: 0}(14 \cdot 42 \%)$, iso$\mathrm{C}_{14: 0}(8 \cdot 32 \%)$, anteiso- $\mathrm{C}_{17: 0}(7 \%)$, iso- $\mathrm{C}_{15: 0}(6 \cdot 13 \%)$, $\mathrm{C}_{16: 0}(5 \cdot 91 \%), \mathrm{C}_{15: 0}(5 \cdot 08 \%), \mathrm{C}_{16: 1} \omega 7 c$ alcohol $(3 \cdot 35 \%)$, $\mathrm{C}_{16: 1} \omega 11 \mathrm{c}(2 \cdot 24 \%)$ and $\mathrm{C}_{14: 0}(1 \cdot 81 \%)$. This profile was similar to those of members of the genus Virgibacillus. The major menaquinone and DAP isomer in the cell-wall peptidoglycan of strain $\mathrm{BH} 30097^{\mathrm{T}}$ were MK-7 and mesoDAP, respectively. Cells of strain $\mathrm{BH} 30097^{\mathrm{T}}$ and O. iheyensis KCTC $3954^{\mathrm{T}}$ contained diphosphatidylglycerol, phosphatidylglycerol and unidentified phospholipids. An unknown aminophospholipid that gave a positive reaction to ninhydrin spraying, reported for some Virgibacillus species by Heyrman et al. (2003), was not detected in strain BH30097 or O. iheyensis KCTC $3954^{\mathrm{T}}$.

DNA was extracted and purified by a modification of the method of Marmur (1961). The DNA G + C content was determined using the reversed-phase HPLC method described by Tamaoka \& Komagata (1984). The DNA G + C 
Table 1. Whole-cell fatty acid composition of strain $\mathrm{BH} 30097^{\top}$ and related Virgibacillus and Oceanobacillus species

Strains: 1, BH30097 ; 2, V. halodenitrificans KCTC $3790^{\mathrm{T}}$; 3, V. pantothenticus KCTC $3539^{\mathrm{T}} ; 4$, V. proomii KCTC $3822^{\mathrm{T}}$; 5 . V. salexigens KCTC $3844^{\mathrm{T}}$; 6, V. marismortui KCTC $3845^{\mathrm{T}} ; 7$, V. carmonensis KCTC $3819^{\mathrm{T}}$; 8, V. necropolis KCTC $3820^{\mathrm{T}}$; 9, V. picturae KCTC $3821^{\mathrm{T}}$; 10 , O. iheyensis KCTC $3954^{\mathrm{T}}$; 11, O. oncorhynchi R-2 ${ }^{\mathrm{T}}$ (data from Yumoto et al., 2005). tr, Trace amount; -, not detected. The positions of double bonds can be located by counting from the methyl $(\omega)$ end of the carbon chain; cis and trans isomers are indicated by the suffixes $c$ and $t$.

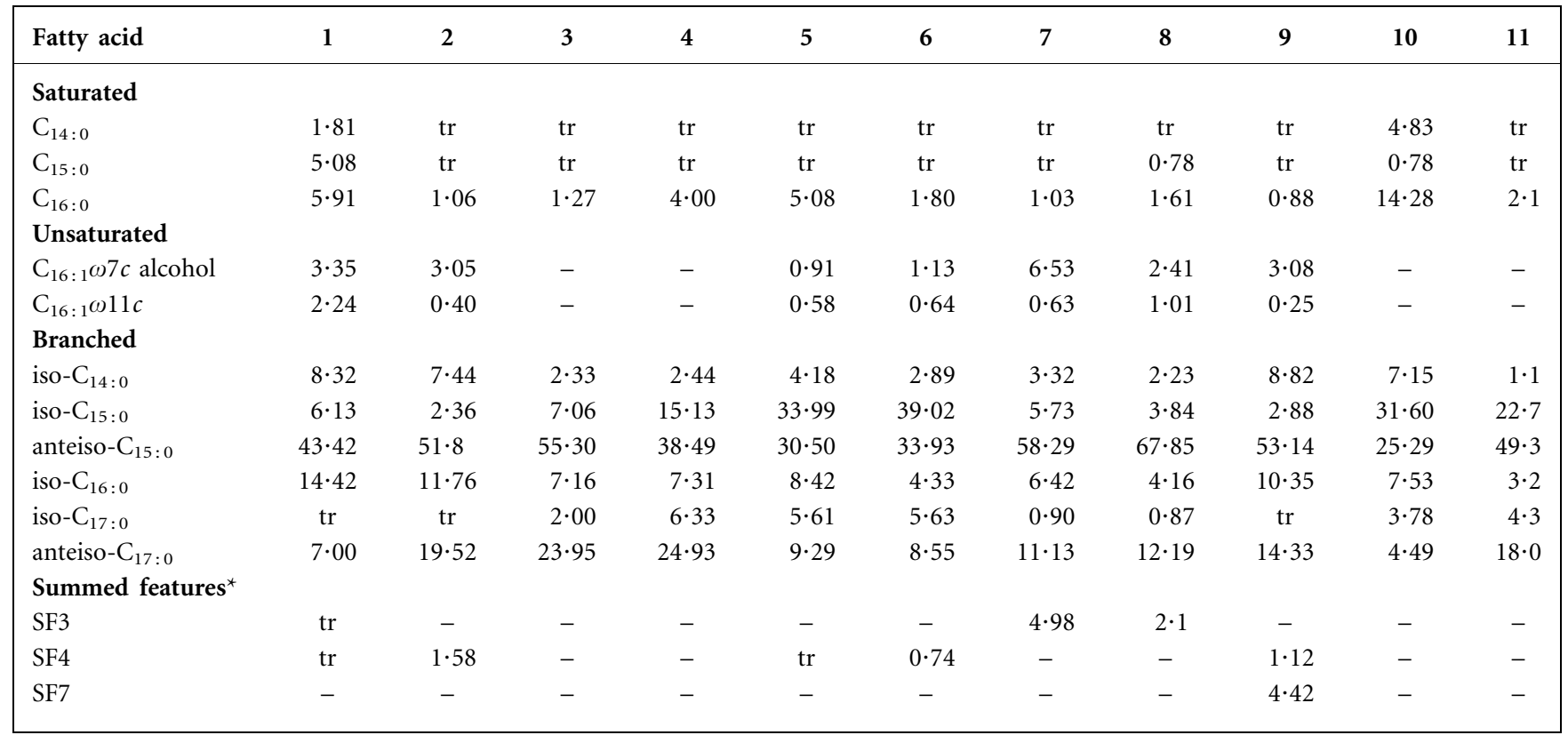

${ }^{*}$ Summed features represent groups of two or three fatty acids that can not be separated by GLC with the MIDI system. SF3, $\mathrm{C}_{16: 1} \omega 7 c$ and/or iso$\mathrm{C}_{15: 0} 2-\mathrm{OH} ; \mathrm{SF} 4$, iso- $\mathrm{C}_{15: 0} 2-\mathrm{OH}$ and/or $\mathrm{C}_{16: 1} \omega 7 t, \mathrm{SF} 7, \mathrm{C}_{18: 1} \omega 7 c, \mathrm{C}_{18: 1} \omega 9 t$ and/or $\mathrm{C}_{18: 1} \omega 12 t$.

contents of BH $30097^{\mathrm{T}}$ and $V$. halodenitrificans KCTC $3790^{\mathrm{T}}$ were 41 and $38 \mathrm{~mol} \%$, respectively.

Two universal primers (9F and 1492R) described by Stackebrandt \& Liesack (1993) were used for PCR amplification of the 16S rRNA gene, and the amplified PCR product was purified using a QIAquick PCR purification kit (Qiagen). The purified 16S rRNA gene was then sequenced using an ABI Prism BigDye Terminator cycle sequencing ready reaction kit (Applied Biosystems), with an automatic DNA sequencer (model 377; Applied Biosystems). Nearly complete 16S rRNA gene sequences (1435 bp) were determined for $\mathrm{BH} 30097^{\mathrm{T}}$ and aligned with those of representatives from the genus Virgibacillus and related taxa using CLUSTAL W software (Thompson et al., 1994). A phylogenetic tree was constructed using the neighbour-joining method (Saitou \& Nei, 1987) based on distance matrix data. Evolutionary distances were calculated using the Jukes \& Cantor (1969) model. The PHYLIP software package (Felsenstein, 1993) was used for all the analyses. The topology of the phylogenetic tree was evaluated using a bootstrap analysis (Felsenstein, 1985) of the neighbour-joining method based on 1000 replications.

The primary structures of the 16S rRNA gene sequence of strain $\mathrm{BH} 30097^{\mathrm{T}}$ were compared with those of closely related reference strains. A phylogenetic tree, based on $K_{\text {nuc }}$ values (Fig. 1), indicated that strain $\mathrm{BH} 30097^{\mathrm{T}}$ belonged to the genus Virgibacillus. Strain $\mathrm{BH} 30097^{\mathrm{T}}$ was phylogenetically most closely related to $V$. halodenitrificans KCTC $3790^{\mathrm{T}}$ (96.7\% 16S rRNA gene sequence similarity). Levels of sequence similarity between strain $\mathrm{BH} 30097^{\mathrm{T}}$ and other Virgibacillus species ranged from $93 \cdot 8$ to $96 \cdot 0 \%$. These values fell within the range that generally can be used to define a novel species (Rossello-Mora \& Amann, 2001; Stackebrandt et al., 2002).

DNA-DNA hybridization was carried out by fluorometric hybridization in microdilution wells using biotinylated DNA (Ezaki et al., 1989). We chose two reference strains, $V$. halodenitrificans KCTC $3790^{\mathrm{T}}$ and Virgibacillus carmonensis KCTC $3819^{\mathrm{T}}$, for the DNA-DNA hybridization experiments, $V$. halodenitrificans KCTC $3790^{\mathrm{T}}$ because it was the strain most closely related to $\mathrm{BH} 30097^{\mathrm{T}}$ and $V$. carmonensis KCTC $3819^{\mathrm{T}}$ as the type species of the genus. As shown in Table 2, DNA-DNA reassociation values between strain $\mathrm{BH} 30097^{\mathrm{T}}$ and the two reference strains were less than $28 \%$, and that between the two reference strains was less than $33 \%$. As such, the $16 \mathrm{~S}$ rRNA gene sequence data comparison and DNA-DNA hybridization results demonstrated that strain $\mathrm{BH} 30097^{\mathrm{T}}$ was most closely related to the genus 


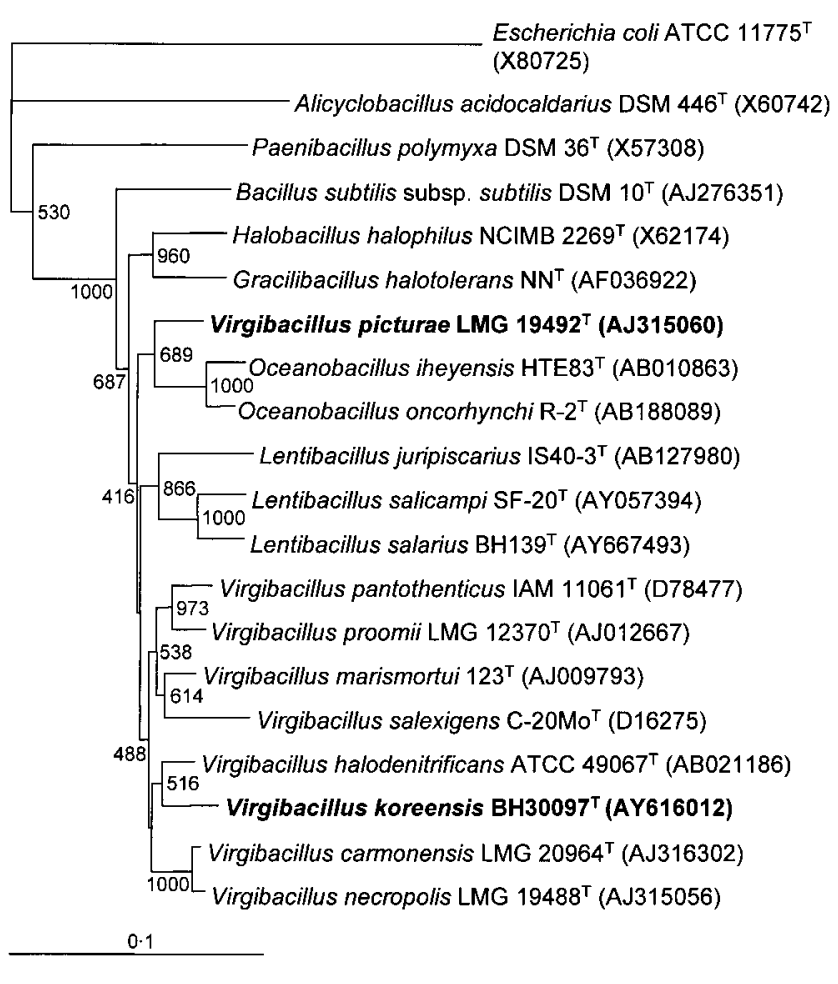

Fig. 1. Neighbour-joining tree showing the phylogenetic position of strain $\mathrm{BH} 30097^{\top}$ with other Virgibacillus species and related taxa based on 16S rRNA gene sequences. Bootstrap values from 1000 resamplings are indicated. Bar, 0.1 accumulated changes per nucleotide.

Virgibacillus but was not a member of any recognized Virgibacillus species.

The genus Virgibacillus is phylogenetically related to the genera Lentibacillus (Yoon et al., 2002; Namwong et al., 2005) and Oceanobacillus (Lu et al., 2001). Oceanobacillus currently comprises two species, O. iheyensis (Lu et al., 2001) and O. oncorhynchi (Yumoto et al., 2005). In our study, we found that $V$. picturae was linked to the genus Oceanobacillus with a bootstrap resampling value of $68 \cdot 9 \%$ (Fig. 1). In the phylogenetic tree constructed using the neighbourjoining algorithm, the genus Oceanobacillus (including $V$.

Table 2. DNA-DNA reassociation values for isolate $\mathrm{BH} 0097^{\top}$, V. halodenitrificans $\mathrm{KCTC} 3790^{\top}$ and V. carmonensis KCTC $3819^{\top}$

\begin{tabular}{|c|c|c|c|}
\hline \multirow[t]{2}{*}{ Strain } & \multicolumn{3}{|c|}{ Reassociation (\%) with labelled DNA from: } \\
\hline & $\mathrm{BH} 30097^{\mathrm{T}}$ & KCTC $3790^{\mathrm{T}}$ & KCTC $3819^{\mathrm{T}}$ \\
\hline $\mathrm{BH} 30097^{\mathrm{T}}$ & 100 & 24 & 28 \\
\hline $\begin{array}{l}\text { V. halodenitrificans } \\
\text { KCTC } 3790^{\mathrm{T}}\end{array}$ & 21 & 100 & 33 \\
\hline $\begin{array}{l}\text { V. carmonensis } \\
\text { KCTC } 3819^{\mathrm{T}}\end{array}$ & 24 & 29 & 100 \\
\hline
\end{tabular}

picturae) formed a distinct clade with Virgibacillus and Lentibacillus (Fig. 1). A phylogenetic tree was also constructed using the maximum-likelihood method (Saitou \& Nei, 1987) based on distance matrix data. Evolutionary distances were calculated using the Jukes \& Cantor (1969) model. The topology of the phylogenetic tree constructed using the maximum-likelihood algorithm was similar to that of the tree constructed using the neighbour-joining algorithm (data not shown). There are currently not enough taxonomic data to distinguish Virgibacillus from Oceanobacillus (Tables 1 and 2). They have similar chemotaxonomic characteristics, such as their major menaquinone (MK-7), cellular fatty acids (anteiso- $\mathrm{C}_{15: 0}$ ) and polar lipids (Table 3). In their fatty acid profiles, genera related to the genus Bacillus have anteiso- $\mathrm{C}_{15: 0}$ as the major cellular fatty acid. V. picturae and the two Oceanobacillus species also had anteiso- $\mathrm{C}_{15: 0}$ as the major fatty acid. Clear differences in the amounts of iso- $\mathrm{C}_{15: 0}$, iso- $\mathrm{C}_{16: 0}$, anteiso- $\mathrm{C}_{17: 0}$ and $\mathrm{C}_{16: 0}$ among $V$. picturae and $O$. iheyensis and $O$. oncorhynchi were observed. $V$. picturae grew at $\mathrm{pH} 7 \cdot 0-10 \cdot 0$, and $O$. iheyensis and $O$. oncorhynchi respectively grew at $\mathrm{pH} 6 \cdot 5-10 \cdot 0$ and $\mathrm{pH} 9 \cdot 0-10 \cdot 0$. These results showed they are facultatively alkaliphilic bacteria, an important characteristic of the genus Oceanobacillus. On the basis of the morphological, physiological and chemotaxonomic characteristics presented and 16S rRNA gene sequence comparisons, it is proposed that Virgibacillus picturae be transferred to the genus Oceanobacillus as Oceanobacillus picturae comb. nov.

Distinctive characteristics of the novel isolate and species of the genera Virgibacillus and Oceanobacillus, taken from previous studies (Arahal et al., 1999, 2000; Denariaz et al., 1989; Heyndrickx et al., 1998, 1999; Heyrman et al., 2003; Lu et al., 2001; Wainø et al., 1999; Yoon et al., 2004; Yumoto et al., 2005), are given in Table 3.

\section{Description of Virgibacillus koreensis sp. nov.}

Virgibacillus koreensis (ko.re.en'sis. N.L. masc. adj. koreensis for Korea, where the type strain was isolated).

Cells are Gram-positive, rod-shaped $(0 \cdot 5-0 \cdot 7 \times 2 \cdot 0-7 \cdot 0 \mu \mathrm{m})$ and motile by means of peritrichous flagella. Ellipsoidal spores are formed in terminal positions. Colonies are circular, low-convex, smooth, semi-translucent and creamcoloured on marine agar. The type strain grows in an anaerobic chamber at $37^{\circ} \mathrm{C}$. The temperature range for growth is $10-45^{\circ} \mathrm{C}$ (optimal at $25^{\circ} \mathrm{C}$ ). The $\mathrm{pH}$ range for growth is $5 \cdot 5-9 \cdot 0$ (optimal at $\mathrm{pH} 7 \cdot 0$ ). No growth occurs with $\mathrm{NaCl}$ concentrations of more than $20 \%$, while optimal growth occurs with a $\mathrm{NaCl}$ concentration of $5-10 \%$. Positive for aesculin hydrolysis, $\beta$-galactosidase, oxidase and catalase activities and acid production from amygdalin, L-arabinose, cellobiose, aesculin, D-fructose, maltose and Dxylose. Negative for nitrate reduction, indole production, glucose acidification, arginine hydrolysis, urease, gelatin hydrolysis and acid production from $\mathrm{N}$-acetylglucosamine, D-arabinose, galactose, L-fucose, glycerol, glycogen, myo-inositol, 5-keto-D-gluconate, mannitol, D-mannose, 
Table 3. Distinctive phenotypic characteristics of strain $\mathrm{BH} 30097^{\top}$ and related Virgibacillus and Oceanobacillus species

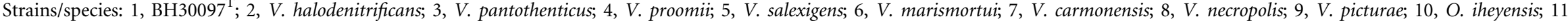

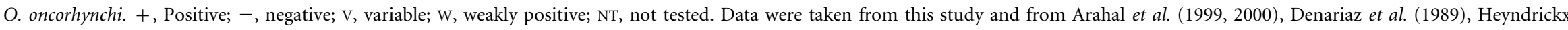
et al. (1998, 1999), Heyrman et al. (2003), Lu et al. (2001), Wainø et al. (1999), Yoon et al. (2004) and Yumoto et al. (2005). All species contain MK-7 as the major menaquinone.

\begin{tabular}{|c|c|c|c|c|c|c|c|c|c|c|c|}
\hline Characteristic & 1 & 2 & 3 & 4 & 5 & 6 & 7 & 8 & 9 & 10 & 11 \\
\hline Pigmentation & - & - & - & - & - & - & Pink & - & - & - & - \\
\hline Chains of cells & - & + & + & + & + & + & - & + & - & - & - \\
\hline \multicolumn{12}{|l|}{ Sporangia: ${ }^{\star}$} \\
\hline Spore shape & $\mathrm{E}$ & $\mathrm{E}$ & ES & ES & $\mathrm{E}$ & $\mathrm{E}$ & ES & $\mathrm{E}$ & ES & $\mathrm{E}$ & $\mathrm{E}$ \\
\hline Spore position & $\mathrm{T}$ & TS & TS & TS & CST & TS & S & CST & $\mathrm{T}$ & TS & s \\
\hline Anaerobic growth & + & + & + & + & - & - & - & - & - & - & + \\
\hline Temperature range $\left({ }^{\circ} \mathrm{C}\right)$ & $10-45$ & $10-45$ & $15-50$ & $15-50$ & $15-45$ & $15->50$ & $10-40$ & $10-40$ & $5-40$ & $15-42$ & $15-40$ \\
\hline \multicolumn{12}{|l|}{ Growth in $\mathrm{NaCl}$ at: } \\
\hline $0 \cdot 5 \%$ & $\mathrm{w}$ & - & + & $\mathrm{w}$ & - & - & - & $\mathrm{w}$ & $\mathrm{w}$ & + & + \\
\hline $25 \%$ & - & $\mathrm{w}$ & - & - & $\mathrm{w}$ & + & - & - & - & - & - \\
\hline \multicolumn{12}{|l|}{ Hydrolysis of: } \\
\hline Gelatin & - & + & + & $\mathrm{V}$ & + & + & - & $\mathrm{w}$ & $\mathrm{w}$ & - & - \\
\hline Aesculin & + & - & + & + & + & + & $\mathrm{W}$ & - & $\mathrm{w}$ & + & NT \\
\hline $\mathrm{H}_{2} \mathrm{~S}$ production & - & - & - & - & + & - & - & - & - & - & NT \\
\hline \multicolumn{12}{|l|}{ Acid production from: } \\
\hline$N$-Acetylglucosamine & - & + & + & + & $\mathrm{W}$ & + & - & $\mathrm{w}$ & $\mathrm{w}$ & $\mathrm{w}$ & - \\
\hline Amygdalin & + & - & + & - & $\mathrm{W}$ & - & - & - & - & - & - \\
\hline D-Arabinose & - & - & + & - & - & - & - & - & - & - & - \\
\hline Galactose & - & + & - & + & $\mathrm{w}$ & - & - & - & $\mathrm{w}$ & - & - \\
\hline D-Glucose & $\mathrm{w}$ & + & - & + & $\mathrm{w}$ & + & - & $\mathrm{w}$ & $\mathrm{w}$ & + & + \\
\hline D-Fructose & + & + & - & + & $\mathrm{w}$ & + & - & $\mathrm{w}$ & $\mathrm{w}$ & + & + \\
\hline L-Fucose & - & - & + & - & - & - & - & - & - & - & - \\
\hline Glycerol & - & $\mathrm{W}$ & + & - & - & $\mathrm{w}$ & - & $\mathrm{W}$ & $\mathrm{w}$ & + & - \\
\hline Glycogen & - & - & - & $\mathrm{V}$ & - & - & - & - & $\mathrm{w}$ & - & - \\
\hline myo-Inositol & - & - & - & + & - & - & - & - & - & - & - \\
\hline 5-Keto-D-gluconate & - & $\mathrm{w}$ & - & - & - & - & $\mathrm{W}$ & $\mathrm{W}$ & - & - & - \\
\hline Mannitol & - & $\mathrm{w}$ & - & - & - & - & - & - & $\mathrm{w}$ & $\mathrm{w}$ & - \\
\hline D-Mannose & - & + & - & + & $\mathrm{w}$ & + & - & $\mathrm{w}$ & $\mathrm{w}$ & + & + \\
\hline D-Melibiose & - & - & - & - & - & - & - & - & $\mathrm{w}$ & - & + \\
\hline L-Rhamnose & - & - & + & $\mathrm{V}$ & - & - & - & - & - & $\mathrm{w}$ & - \\
\hline D-Trehalose & $\mathrm{W}$ & + & + & + & - & - & - & $\mathrm{w}$ & $\mathrm{w}$ & - & + \\
\hline D-Turanose & - & - & + & - & - & - & - & - & $\mathrm{w}$ & $\mathrm{w}$ & - \\
\hline Polar lipids $\dagger$ & $\begin{array}{c}\text { PG, } \\
\text { DPG, PLs }\end{array}$ & $\begin{array}{c}\text { PG, } \\
\text { DPG, PLs }\end{array}$ & $\begin{array}{c}\text { PG, DPG, } \\
\text { PE, PLs, APL }\end{array}$ & $\begin{array}{c}\text { PG, DPG, } \\
\text { PE, PLs, APL }\end{array}$ & $\begin{array}{c}\text { PG, DPG, } \\
\text { PLs }\end{array}$ & $\begin{array}{c}\text { PG, DPG, } \\
\text { PE, PLs, APL }\end{array}$ & $\begin{array}{c}\text { PG, DPG, } \\
\text { PLs }\end{array}$ & $\begin{array}{c}\text { PG, DPG, } \\
\text { PLs }\end{array}$ & $\begin{array}{c}\text { PG, DPG, } \\
\text { PLs }\end{array}$ & $\begin{array}{c}\text { PG, DPG, } \\
\text { PLs }\end{array}$ & NT \\
\hline DNA G $+\mathrm{C}$ content $(\mathrm{mol} \%)$ & 41 & 38 & $37-38$ & 37 & $36-40$ & $39-43$ & 40 & 37 & 40 & 36 & $38 \cdot 5$ \\
\hline
\end{tabular}

*Spore shape: E, ellipsoidal; S, spherical. Spore position: T, terminal; S, subterminal; C, central.

$\nmid$ PG, Phosphatidylglycerol; DPG, diphosphatidylglycerol; PE, phosphatidylethanolamine; PLs, unidentified phospholipids; APL, unknown aminophospholipid. 
D-melibiose, L-rhamnose and D-turanose. The DNA G + C content is $41 \mathrm{~mol} \%$, the major isoprenoid quinone is $\mathrm{MK}-7$ and the major cellular fatty acids are anteiso- $\mathrm{C}_{15: 0}$ and iso$\mathrm{C}_{16: 0}$. The cell-wall peptidoglycan contains meso-DAP.

The type strain, BH $30097^{\mathrm{T}}\left(=\mathrm{KCTC} 3823^{\mathrm{T}}=\mathrm{JCM} 12387^{\mathrm{T}}\right)$, was isolated from a salt field near Taean-Gun on the Yellow Sea in Korea.

\section{Emended description of genus Oceanobacillus Lu et al. 2002}

Oceanobacillus (O.ce.a.no.ba.cil'lus. Gr. n. okeanos the ocean; L. dim. n. bacillus a small rod; N.L. masc. n. Oceanobacillus the ocean bacillus/rod).

Gram-positive, spore-forming rods, motile by means of peritrichous flagella. Ellipsoidal spores are subterminal or terminal within swollen sporangia. Obligately aerobic or facultatively anaerobic, obligately or facultatively alkaliphilic and grow at $0-22 \%(\mathrm{w} / \mathrm{v}) \mathrm{NaCl}$. Catalase and oxidase reactions are positive. Growth occurs at $5-42^{\circ} \mathrm{C}$. The predominant cellular fatty acid is anteiso- $\mathrm{C}_{15: 0}$. The major isoprenoid quinine is MK-7. The DNA G $+\mathrm{C}$ content is $35 \cdot 8-40 \mathrm{~mol} \%$. The type species is Oceanobacillus iheyensis.

\section{Description of Oceanobacillus picturae (Heyrman et al. 2003) comb. nov.}

Oceanobacillus picturae (pic.tu'rae. L. gen. n. picturae pertaining or belonging to a painting).

Basonym: Virgibacillus picturae Heyrman et al. 2003.

The description matches that given by Heyrman et al. (2003). The type strain is strain LMG $19492^{\mathrm{T}}$ (=DSM $14867^{\mathrm{T}}=$ KCTC $3821^{\mathrm{T}}$ ).

\section{Acknowledgements}

The authors would like to thank Professor Hans G. Trüper for his advice in naming the organisms. This research was supported by the 21C Frontier Microbial Genomics and the Application Center program, Ministry of Science \& Technology (grant MG05-0101-1-0), Korea, and KRIBB Research Initiative Program.

\section{References}

Arahal, D. R., Marquez, M. C., Volcani, B. E., Schleifer, K. H. \& Ventosa, A. (1999). Bacillus marismortui sp. nov., a new moderately halophilic species from the Dead Sea. Int J Syst Bacteriol 49, 521-530.

Arahal, D. R., Marquez, M. C., Volcani, B. E., Schleifer, K. H. \& Ventosa, A. (2000). Reclassification of Bacillus marismortui as Salibacillus marismortui comb. nov. Int J Syst Evol Microbiol 50, 1501-1503.

Denariaz, G., Payne, W. J. \& Le Gall, J. (1989). A halophilic denitrifier, Bacillus halodenitrificans sp. nov. Int J Syst Bacteriol 39, 145-151.

Ezaki, T., Hashimoto, Y. \& Yabuuchi, E. (1989). Fluorometric deoxyribonucleic acid-deoxyribonucleic acid hybridization in microdilution wells as an alternative to membrane filter hybridization in which radioisotopes are used to determine genetic relatedness among bacterial strains. Int J Syst Bacteriol 39, 224-229.

Felsenstein, J. (1985). Confidence limits on phylogenies: an approach using the bootstrap. Evolution 39, 783-791.

Felsenstein, J. (1993). PHYLIP - Phylogeny Inference Package, version 3.5c. Distributed by the author. Department of Genome Sciences, University of Washington, Seattle, USA.

Garabito, M. J., Arahal, D. R., Mellado, E., Marquez, M. C. \& Ventosa, A. (1997). Bacillus salexigens sp. nov., a new moderately halophilic Bacillus species. Int J Syst Bacteriol 47, 735-741.

Heyndrickx, M., Lebbe, L., Kersters, K., De Vos, P., Forsyth, G. \& Logan, N. A. (1998). Virgibacillus: a new genus to accommodate Bacillus pantothenticus (Proom and Knight 1950). Emended description of Virgibacillus pantothenticus. Int J Syst Bacteriol 48, 99-106.

Heyndrickx, M., Lebbe, L., Kersters, K., Hoste, B., De Wachter, R., De Vos, P., Forsyth, G. \& Logan, N. A. (1999). Proposal of Virgibacillus proomii sp. nov. and emended description of Virgibacillus pantothenticus (Proom and Knight 1950) Heyndrickx et al. 1988. Int J Syst Bacteriol 49, 1083-1090.

Heyrman, J., Logan, N. A., Busse, H.-J., Balcaen, A., Lebbe, L., Rodriguez-Diaz, M., Swings, J. \& De Vos, P. (2003). Virgibacillus carmonensis sp. nov., Virgibacillus necropolis sp. nov. and Virgibacillus picturae sp. nov., three novel species isolated from deteriorated mural paintings, transfer of the species of the genus Salibacillus to Virgibacillus, as Virgibacillus marismortui comb. nov. and Virgibacillus salexigens comb. nov., and emended description of the genus Virgibacillus. Int J Syst Evol Microbiol 53, 501-511.

Jukes, T. H. \& Cantor, C. R. (1969). Evolution of protein molecules. In Mammalian Protein Metabolism, pp. 21-132. Edited by H. N. Munro. New York: Academic Press.

Komagata, K. \& Suzuki, K. (1987). Lipid and cell-wall analysis in bacterial systematics. Methods Microbiol 19, 161-207.

Lapage, S. P., Sneath, P. H. A., Lessel, E. F., Skerman, V. B. D., Seeliger, H. P. R. \& Clark, W. A. (1992). International Code of Nomenclature of Bacteria (1990 Revision). Bacteriological Code. Washington, DC: American Society for Microbiology.

Lee, J.-S., Jung, M.-C., Kim, W.-S. \& 10 other authors (1996). Identification of lactic acid bacteria from kimchi by cellular FAMEs analysis. Kor J Appl Microbiol Biotechnol 24, 234-241.

Lim, J.-M., Jeon, C. O., Song, S. M. \& Kim, C.-J. (2005). Pontibacillus chungwhensis gen. nov., sp. nov., a moderately halophilic Grampositive bacterium from a solar saltern in Korea. Int J Syst Evol Microbiol 55, 161-170.

Lu, J., Nogi, Y. \& Takami, H. (2001). Oceanobacillus iheyensis gen. nov., sp. nov., a deep-sea extremely halotolerant and alkaliphilic species isolated from a depth of $1050 \mathrm{~m}$ on the Iheya Ridge. FEMS Microbiol Lett 205, 291-297.

Marmur, J. (1961). A procedure for the isolation of DNA from microorganisms. J Mol Biol 3, 208-218.

Namwong, S., Tanasupawat, S., Smitinont, T., Visessanguan, W., Kudo, T. \& Itoh, T. (2005). Isolation of Lentibacillus salicampi strains and Lentibacillus juripiscarius sp. nov. from fish sauce in Thailand. Int J Syst Evol Microbiol 55, 315-320.

Rossello-Mora, R. \& Amann, R. (2001). The species concept for prokaryotes. FEMS Microbiol Rev 25, 39-67.

Saitou, N. \& Nei, M. (1987). The neighbor-joining method: a new method for reconstructing phylogenetic trees. Mol Biol Evol 4, 406-425.

Schlesner, H., Lawson, P. A., Collins, M. D., Weiss, N., Wehmeyer, U., Völker, H. \& Thomm, M. (2001). Filobacillus milensis gen. nov., sp. nov., a new halophilic spore-forming bacterium with Orn-D-Glutype peptidoglycan. Int J Syst Evol Microbiol 51, 425-431. 
Shin, Y. K., Lee, J.-S., Chun, C. O., Kim, H.-J. \& Park, Y.-H. (1996). Isoprenoid quinone profiles of the Leclercia adecarboxylata KCTC $1036^{\mathrm{T}}$. J Microbiol Biotechnol 6, 68-69.

Skerman, V. B. D. (1967). A Guide to the Identification of the Genera of Bacteria, 2nd edn. Baltimore: Williams \& Wilkins.

Sorokin, D. Y. (2005). Is there a limit for high-pH life? Int J Syst Evol Microbiol 55, 1069-1075.

Spring, S., Ludwig, W., Marquez, M. C., Ventosa, A. \& Schleifer, K.-H. (1996). Halobacillus gen. nov., with description of Halobacillus litoralis sp. nov. and Halobacillus trueperi sp. nov., and transfer of Sporosarcina halophila to Halobacillus halophila comb. nov. Int J Syst Bacteriol 46, 492-496.

Stackebrandt, E. \& Liesack, W. (1993). Nucleic acids and classification. In Handbook of New Bacterial Systematics, pp. 152-189. Edited by M. Goodfellow \& A. G. O'Donnell. London: Academic Press.

Stackebrandt, E., Frederikson, W., Garrity, G. M. \& 10 other authors (2002). Report of the ad hoc committee for the re-evaluation of the species definition in bacteriology. Int J Syst Evol Microbiol 52, 1043-1047.

Tamaoka, J. \& Komagata, K. (1984). Determination of DNA base composition by reversed phase high-performance liquid chromatography. FEMS Microbiol Lett 25, 125-128.

Thompson, J. D., Higgins, D. G. \& Gibson, T. J. (1994). CLUSTAL W: improving the sensitivity of progressive multiple sequence alignment through sequence weighting, position-specific gap penalties and weight matrix choice. Nucleic Acids Res 22, 4673-4680.

Wainø, M., Tindall, B. J., Schumann, P. \& Ingvorsen, K. (1999). Gracilibacillus gen. nov., with description of Gracilibacillus halotolerans gen. nov., sp. nov.; transfer of Bacillus dipsosauri to Gracilibacillus dipsosauri comb. nov., and Bacillus salexigens to the genus Salibacillus gen. nov., as Salibacillus salexigens comb. nov. Int J Syst Bacteriol 49, 821-831.

Yang, P., Vauterin, L., Vancaneyt, M., Swings, J. \& Kersters, K. (1993). Application of fatty acid methyl esters for the taxonomic analysis of the genus Xanthomonas. Syst Appl Microbiol 16, 47-71.

Yoon, J.-H., Kang, K. H. \& Park, Y.-H. (2002). Lentibacillus salicampi gen. nov., sp. nov., a moderately halophilic bacterium isolated from a salt field in Korea. Int J Syst Evol Microbiol 52, 2043-2048.

Yoon, J. H., Oh, T. K. \& Park, Y. H. (2004). Transfer of Bacillus halodenitrificans Denariaz et al. 1989 to the genus Virgibacillus as Virgibacillus halodenitrificans comb. nov. Int J Syst Evol Microbiol 54, 2163-2167.

Yumoto, I., Yamazaki, K., Sawabe, T., Nakano, K., Kawasaki, K., Ezura, Y. \& Shinano, H. (1998). Bacillus horti sp. nov., a new Gramnegative alkaliphilic bacillus. Int J Syst Bacteriol 48, 565-571.

Yumoto, I., Horota, K., Nodasaka, Y. \& Nakajima, K. (2005). Oceanobacillus oncorhynchi sp. nov., a halotolerant obligate alkaliphile isolated from the skin of a rainbow trout (Oncorhynchus mykiss), and emended description of the genus Oceanobacillus. Int J Syst Evol Microbiol 55, 1521-1524. 